\title{
Resettlement of Russian Immigrants in Israel: 1989-93
}

\author{
Judith T. Shuval
}

\section{The Meaning of Immigration in Israeli Society}

Immigration has been an ongoing process in Israel during its entire history, including the period predating independence. It is of central significance that one of the first legislative acts passed by the Knesset (the Israeli Parliament) after the declaration of independence in 1948 was the Law of Return, which stated that every Jew has the right to immigrate and settle in Israel. This formal open-door policy accepts virtually all Jewish immigrants and views their arrival as a symbolic reaffirmation of the fundamental raison d'être of the society.

Pragmatic considerations of economic need, job availability, or physical fitness have not served, as in other countries, as criteria for admission. The "ingathering of the exiles," defined as the acceptance and integration of Jewish immigrants who may be forced to immigrate or who freely opt to come, continues to represent one of the cardinal values of Israeli society, which has allocated major resources to the absorption process. In addition to the ideological commitment, immigration has been seen as fulfilling the need to augment the population in order to strengthen the economic and social foundations of the society.

The assumption has been that the society and its economic structure must be adapted to the economic and social needs of the immigrants rather than the reverse. In fact, a variety of publicly sponsored intervention programs and benefits are offered to promote immigrants' entry into the society. These include language courses, hostels for immediate housing, tax breaks, import privileges,

Professor Judith $T$. Shuval is attached to the Faculty of Sociology, Hebrew University of Jerusalem, Israel. rental subsidies, housing mortgages at favourable rates, and small business loans on preferential terms.

There have been periodic protests regarding the priority in allocation of resources to immigrants by various deprived groups in the society: slum dwellers, disabled persons, veteran soldiers, and young couples. But none has changed the basic priority that has been accorded to admission of immigrants and the national commitment to their needs.

\section{Motives and Background of Russian Immigrants}

In recent years, there have been two major waves of immigration from Russia to Israel. During the 1970 s, when the Soviet regime was still in its prime, some 137,000 Jews left the Soviet Union to settle in Israel. Between 1989 and 1993 -after the collapse of the Soviet Union-over three times that number, 450,000 , arrived in Israel. While the background, motives, and social and political circumstances of the two waves of immigration differ, they are not unrelated. This paper focuses on the more recent group of immigrants but will refer briefly to the earlier settlers as well. (For research on immigration from the Soviet Union in the 1970s, see Friedgut 1984; Gitelman 1982, 1985; Horowitz 1986, 1989; Ofer and Vinokur 1989; Shuval 1983, 1984, 1985; and Simon 1985.)

The most recent wave of immigration began in 1989 after the collapse of the Soviet Union, against a background of glasnost and perestroika. The newly-found freedom from an oppressive, autocratic, and decadent regime was accompanied by widespread social unrest, economic instability, and public exposure of the corruption and malfunctioning of most of the major social institutions including government offices, the army, the health care system, schools, and industry. The col- lapse in social order and the widespread anomie-loss of norms and values - unleashed forces of chauvinism and ethnic conflict. Previously clandestine anti-Semitism has been openly expressed in the media by populist leaders eager to blame the ubiquitous social problems on minority groups and specifically on the Jews. "Pamiat" has publicly demanded expulsion of Jews and rumours of coming pogroms have been widely circulated; Vladimir Zhirinovsky is only the most candidly outspoken and visible of anti-Semitic figures (Baizer, 1992).

Growing evidence of virulent, uncontrolled anti-Semitism served as the principal motive for the large-scale immigration of Jews to Israel in the 1990s. In addition, for many, disillusionment with the Soviet system brought a sense of diminishing confidence that effective, democratic solutions would be found for the massive economic and social problems that came in the wake of that system's collapse. Despite the fact that Jews were

Table 1. Immigrants to Israel from Russia, 1965-93

\begin{tabular}{lr} 
Period & Number \\
$1965-71$ & 24,730 \\
$1972-79$ & 137,134 \\
1972 & 31,652 \\
1973 & 33,477 \\
1974 & 16,816 \\
$1980-84$ & 11,549 \\
$1985-89$ & 18,205 \\
1990 & 184,602 \\
1991 & 147,292 \\
1992 & 64,648 \\
1993 (Aug.) & 41,126 \\
Total & 711,231 \\
\hline
\end{tabular}

Refuge, Vol. 14, No. 6 (November 1994) 
more freely admitted to the universities, became more active in political life and liberal causes, and gained access to jobs that had previously been closed to them, there was growing fear of the future. Lack of control over the newlyindependent states raised concern over the possibility of further ecological disasters similar to Chernobyl. Even if some preferred other destinations, Israel is open, accessible and, despite many difficulties, provides a relatively supportive social environment for immigrants. Relatives in Israel who had settled during the 1970s encouraged immigration, and there were periodic rumours and panic that Russia might suddenly limit emigration again or that Israel might limit entry (Baizer 1992).

Eighty percent of the immigrants of the 1990s have come from Russia, the Ukraine, Byelorussia, Baku, Moldavia, and Uzbekistan-areas where Jewish traditions and identity were minimal. Compared to the 1970 s, fewer have come from the Balkan republics where Jewish traditions and identity were relatively strong. Thirteen percent of the recent immigrants are from the Asian republics and 7 percent from the Caucasian republics (Naveh et al. 1993). Demographically, the immigrants differ from the 1970 s group. The population includes more elderly than before; the high divorce rates in Russia have resulted in a high proportion of single-parent families, mostly headed by women. There is a relatively high proportion of non-Jews in mixed marriages.

What is most striking about this wave of immigration, as indicated in Table 1, is its absolute and relative size. In the early 1990s, the population of Israel was just over 4 million, so that 450,000 immigrants comprised over 10 percent of the total. This means that the size of the work force seeking to enter the occupational system is extremely large. These immigrants are also very well-educated: 60 percent are engineers, technicians, teachers, physicans, scientists, musicians, or performers. This wave of immigration resulted in Israel's population being one of the most educated in the world, with between 11 and 14 percent of universityeducated people. The critical issue facing the society is how to take advantage of this high-quality scientific and technical talent (Ofer et al. 1991).

The immigrants of the 1990 s found in Israel a society in which successful efforts to control runaway inflation resulted in an unemployment rate of 10 percent before the large-scale immigration from Russia started. As in many countries experiencing a crisis in an over-extended welfare state, there has been growing attention in government circles to cost effectiveness, rational planning, curtailing welfare services, and setting limits on public spending. Past experience has shown that, in the long run, it is dysfunctional to encourage over-dependence on the public services. There is growing encouragement of private initiatives and a general reduction in government intervention.

\section{Occupational Patterns}

During the past twenty years, there have been major changes in the occupational structure of the Israeli society. This is seen in the increased proportion of persons with academic training in the professions and in administration. The proportion of office workers and sales personnel has grown, while the number of persons working in agriculture, industry, and construction has decreased. Services, both public and private, have grown as have the financial and business sectors. The striking difference between the occupational structure of the immigrant population and the Israeli labour force is seen in Table 2 . The immigrants are characterized by large groups of university graduates, engineers, architects, physicians and dentists, middle-school teachers, and computer technologists; the Israeli work force has higher proportions of post-primary teachers, administrative, clerical and sales personnel, agricultural workers, and industrial workers. Table 3 presents the same comparison by grouped sets of occupations which make the differences between them clearer.

It is widely believed that the rate of downward occupational change among the recently arrived immigrants will be greater than it was for Russian immigrants from the Soviet Union who arrived in the 1970 s. This is partly a result of the fact that some occupations are already saturated; a dramatic example is medicine. Over 12,000 Russian physicians arrived in Israel between 1989 and 1993, and it is estimated that the health care system will be able to absorb only 2,000 of them. This is in sharp contrast to the earlier period, when 95 percent of the immigrant physicians were employed

Table 2. Comparison of Selected Occupations among 1990 Immigrants with 1989 Israeli Total Labour Force Immigrants Labour 19901989

University graduates, natural sciences

Engineers, architects Physicians, dentists

Post-primary teachers $\%$

Middle-school teachers

Tech., practical engineers, computer specialists

Admin., management

Clerical

Sales

Service

Agriculture

Skilled industry, construction, transport

Other

$$
1.6
$$

25.0

Table 3. Grouped Occupation: Comparison of 1990 Immigrants with Israeli Labour Force (1989) Immigrants Labour 19901989

$\% \quad \%$

University graduates

40.6

Technically trained

34.3

Skilled workers

$12.6 \quad 23.0$

Clerical, sales, unskilled $\quad 12.5 \quad 46.6$

Total

100100

Source: Ofer, G. et al. 1991 
in their profession (Ofer and Vinokur 1989). With regard to other occupations, it is still too early to determine if, after a period of retraining, some immigrants who have changed their occupation in order to make ends meet, will return to their original occupation or even improve their status in the long run.

One of the complicating factors in analyzing occupational change in this population stems from the fact that some occupations have different names in Russia and in Israel: for example, certain types of "engineers" in Russia are defined as technicians in Israel.

Employment of this large pool of skilled persons requires a major input of investment capital that would move the economy into a rapid growth phase. Clearly, this is dependent on progress in the peace process. In mid1994, economic indicators show that this turnaround in the economy has already started. In the long run, there

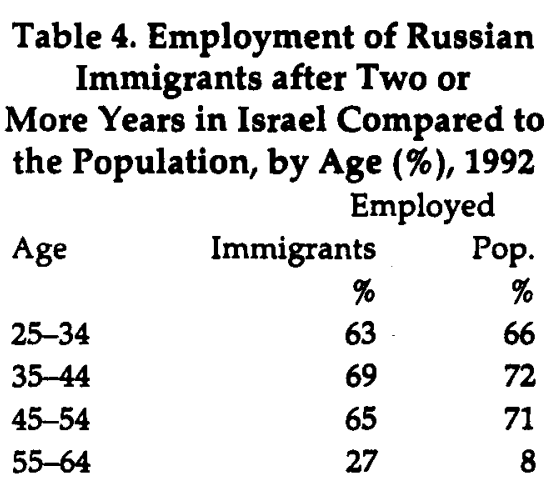

Table 5. Employment of Russian Immigrants

by Age and Gender (1989-92) Employed

$\begin{array}{lrrr}\text { Age } & \text { Total } & \text { Males } & \text { Females } \\ & \% & \% & \% \\ 25-29 & 60 & 69 & 51 \\ 30-34 & 57 & 76 & 40 \\ 35-39 & 61 & 71 & 52 \\ 40-44 & 55 & 71 & 40 \\ 45-49 & 43 & 71 & 25 \\ 50-54 & 48 & 64 & 38 \\ 55-59 & 32 & 54 & 16 \\ 60-64 & 16 & 27 & 5\end{array}$

Source: Naveh, G. et al. 1993 will be growth in high-tech industries, especially chemicals, metals, electricity and electronics, and in the essential sectors of the infrastructure such as construction, communications, and transportation. In future years, it is expected that these will expand and employ many of the highly-trained immigrants.

The expansion of these industries depends on the encouragement of investment and on the provision of incentives in the form of government loan guarantees. But there is an inevitable time gap during which immigrants have no choice but to seek employment in alternative sectors which, in many cases, do not suit their skills. Indeed, feedback from immigrants in Israel to their friends and families in Russia concerning difficulties they are now encountering has resulted in fewer arrivals in 1992 and 1993, and in a lowering in the level of skills among the more recent arrivals. Thus, 27 percent of the 1990 immigrants were engineers while only 19 percent of the 1992 immigrants were trained in that profession. The proportion of unskilled workers increased from 15 to 25 percent during that period.

A study of the employment status of immigrants from the former Soviet Union who arrived between October 1989 and February 1992 was carried out from July to September, 1992, when the respondents had been in Israel from 6 months to two-and-a-half years. The research was based on a sample of 1,200 immigrants aged 2564 , living in 30 communities in Israel, who were interviewed in their homes by Russianspeaking interviewers (Naveh et al. 1993).

The study shows that passage of time has a positive effect on general employment status: the longer immigrants are in the country, the more likely they are to be employed, although not necessarily in the occupation for which they had been trained. About one-half of the total immigrant population surveyed was employed but, among those who have been in Israel for two-and-a-half years, 62 percent were working. Except for the oldest group of immigrants (aged 55-64), this percentage employed is only slightly lower than in comparable age groups of the veteran Jewish population: see Table 4. Among the immigrants recorded as not working, 17 percent are studying or participating in various retraining courses, while 40 percent are actively seeking work.

The study shows that gender and age are critical factors in employment status. In all age groups, men are more likely to be employed than women, and the likelihood of employment decreases with age in both genders: see Table 5. When retraining is needed, employers tend to prefer younger trainees. The sharp decline in employment comes at an earlier age among women (at age 40) than among men.

Immigrants whose occupations before coming to Israel were in the industrial and technical sector are the most likely to be employed in Israel: 69 percent. Of these, 52 percent were working as skilled workers in industry. Among those trained as engineers, 60 percent were employed, one-third of them as engineers and another 11 percent as technicians and programmers.
Table 6. Russian Immigrants to Israel, 1989-92: Selected Measures of Job Satisfaction by Gender and Age (\%)

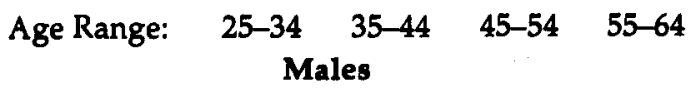

$\begin{array}{lllll}\text { Working in desired occupation } & 51 & 48 & 29 & 25\end{array}$

Satisfied with job

Satisfied that skills are utilized

$51 \quad 44 \quad 38$

$47 \quad 41 \quad 27$

34

Working in desired occupation

39

Satisfied with job

Females

Satisfied that skills are utilized

49

34

23

19

36

53

36

27

Source: Naveh, G. et al. 1993

Refuge, Vol. 14, No. 6 (November 1994) 
Among immigrant physicians and teachers, only one-third are employed and about one-quarter of these are in the service occupations.

Table 6 indicates that when immigrants from the former Soviet Union are asked to evaluate their workstatus, two consistent patterns emerge: satisfaction decreases with age, and women are less satisfied with their work than men. It is undoubtedly a reflection of employers' preferences that, for both male and female immigrants, the steep decline in satisfaction occurs in the 4554 age group. Many employers view the age of $\mathbf{4 5}$ as too old for effective retraining. The implication of these findings is that older immigrants, and especially the women among them, experience the greatest difficulty in finding satisfactory work.

Although the overall rates of employment are relatively high, this does not mean that Russian immigrants are having an easy time in the 1990 s. Many are having difficulty making ends meet; employment in low-ranking service occupations provides low remuneration; rent and food are expensive. The feeling that one's skills and training are not being utilized serves as an ongoing source of frustration. As noted, the older segments of the immigrant population and the women are especially vulnerable, because the age of those viewed by employers as too old to be employable has been sharply reduced. Thus people at the age of 45 , who were at the height of a career, find themselves defined as too old to be employed in their profession. Women of all ages are disadvantaged in the job market relative to men of comparable age, and this is especially true of older women.

\section{Earlier Immigrants: A Significant Reference Group}

Immigrants from the Soviet Union who settled in Israel during the 1970s $(137,000$ persons) serve as a significant reference group for the immigrants of the 1990s. The role of the former group is somewhat ambiguous, providing both positive and negative functions. On the positive side, the group in- cludes family and friends who, in many cases, ease the entry of newer arrivals by providing practical information laced with experience on how to get along in Israeli society. They serve as important sources of social support and provide a comfortable language-based group in which immigrants can feel at home. On a symbolic level, their presence serves to make real the prospect of successful social and economic integration.

For some of the recent immigrants, on the other hand, the 1970s immigrants serve as a negative reference group-the success of which exacerbates the difficulties of the more recent arrivals and causes them to think that, under the current economic and social circumstances, they themselves are unlikely to reach the level of successful integration they see among the earlier group. The contrast in the job market in the two periods is especially hard to accept. For example, the 12,000 physicians who arrived during the 1990 s cannot help looking back with some envy (possibly bitterness) at the earlier situation (in which virtually all of the physicians were employed in their profession) in light of the present reality, in which only one in six of these immigrant physicians will be so employed.

\section{Conclusion}

The full story about the resettlement of Russian immigrants in Israel in the 1990 s is only emerging. Four years is a short period in the overall process of adjustment and acculturation; the research that presents reliable findings is just beginning to accumulate, and so far only selected findings have been published. However, despite differences in the historical context and in the economic and social circumstances, the experience of the 1970s leads us to be generally optimistic about the long-range prospects. This is not meant to diminish or ignore the many problems involved, many of which are painful for many people. The factors most conducive to optimism are: (1) the remarkable educational and occupational level of the immigrants; (2) their high level of mo- tivation and adaptability to the exigencies of their new social setting; (3) the strong likelihood of dramatic economic development in the Israeli economy through major input of capital; and, perhaps most important of all, (4) the ongoing peace process between Israel and its Arab neighbours which, despite sporadic setbacks, will in the long run bring a renaissance of development to the benefit of the entire region.

\section{References}

Baizer, M. 1992. Da Me'Ayin Banu. Jerusalem: Ministry of Education. Hebrew.

Friedgut, T. H. 1984. "The Welcome Home: Absorption of Soviet Jews in Israel." The Decisive Decade: Soviet Jewry, 1971-1980, edited by R.O. Freedman. Durham, N.C.: Duke University Press.

Gitelman, Z. 1982. "Soviet Immigrant Resettlement in the United States." Soviet Jewish Affairs, 12, 2, pp. 11-13.

Gitelman, Z. 1985. "The Quality of Life in Israel and the United States." In New Lives: The Adjustment of Soviet Jewish Immigrants in the United States and Israel, edited by R. Simon, pp. 47-68. Lexington, Mass.: Lexington Books.

Horowitz, T. R. 1986. Between Two Worlds: Children from the Soviet Union in Israel. New York: University Press of America.

-1989. The Soviet Man in an Open Society. New York: University Press of America.

Israel Central Bureau of Statistics. 1992. Statistical Abstract of Israel No. 22. Jerusalem.

Naveh, G., G. Noam, and E. Benita. 1993. Employment and Economic Status: Selected Findings from a National Survey of Immigrants from Russia. Jerusalem: Brookdale Institute for Gerontology and Adult Human Development. Hebrew.

Ofer, G., A. Vinokur, and Y. Bar-Haim. 1989. "The Absorption and Economic Contribution of Immigrants from the USSR in Israel." In T.R. Horowitz, The Soviet Man in an Open Society, pp. 67-91. New York: University Press of America.

Ofer, G., K. Flug, and N. Kassir. 1991. "The Absorption in Employment of Immigrants from the Soviet Union: 1990 and Beyond." Economic Quarterly 148:135-171. Hebrew.

Shuval, J.T. 1983. Newcomers and Colleagues: Soviet Immigrant Physicians in Israel. Galveston: Cap and Gown Press.

Shuval, J.T. 1984. "Soviet Immigrant Physicians in Israel." Soviet Jewish Affairs, 14, pp. 19-40.

Shuval, J.T. 1985. "Social Functions of Medical Licensing: A Case Study of Soviet Immigrant Physicians in Israel." Social Science and Medicine, 20, 9, pp. 901-9.

Simon, R.J. 1985. New Lives: The Adjustment of Soviet Jewish Immigrants in the United States and Israel. Lexington, Mass.: Lexington Books. J 